\title{
趣 \\ PATOLOGI PEMBANGUNAN ETIKA POLITIK PASCAREFORMASI DALAM PERSPEKTIF POSTSTRUKTURALIS-HIPERSEMIOTIK
}

\author{
Darsono \\ Program Studi Magister Ilmu Politik \\ FISIP Universitas Wijaya Kusuma Surabaya \\ Email:darsono_fbs@uwks.ac.id \\ Clara Aprillia \\ Program Studi Magister Ilmu Politik \\ FISIP Universitas Wijaya Kusuma Surbaya \\ Email: claraaprillia@gmail.com
}

\begin{abstract}
Abstrak
Politik Indonesia pascareformasi diwarnai dengan patologi pembangunan. Untuk mengungkap problematika tersebut, fokus kajian ini mencakupi (1) bentuk simbol-simbol anomali dalam perpolitikan Indonesia, (2) fenomena paradoks pembangunan yang tampak dalam etika politik pascareformasi. Metode yang digunakan dalam penelitian ini adalah metode kualitiatif. Sedangkan teori yang digunakan adalah teori postruktural-hipersemiotik. Hasil penelitian ini merupakan negasi atau kritik, sebagaimana penegasan atas eksistensi etika sebagai suatu fenomena yang selama ini tenggelam oleh kapitalisme-modernis yang bergerilya mengatur ideologi massa melalui oligarki kekuasaan dengan jargon pembangunan. Simbol-simbol anomali itu mewujud dalam berbagai sektor, terutama pada sektor ekonomi, pendidikan, hukum, kesehatan, dan politik; sedangkan paradoks pembangunan tampak pada proyek opportunity cost dan kompetisi pembangunan.
\end{abstract}

Kata Kunci : Patologi, anomali, paradoks, pascareformasi, etika politik, hipersemiotik, eksistensialisme-etis, postruktural.

\begin{abstract}
Post-reform Politics in Indonesia marks by development pathologies. The focus of this study covers (1) anomalous symbols in Indonesian politics, (2) the paradoxical development of phenomena that appears in post-reform political ethics. This study uses qualitative method. While, poststructural-hypersemiotic used as a theory. The results show negation or criticism, as is the affirmation of the existence of ethics as a phenomenon that has been drowned by modernist-capitalism, which guerrillas regulates mass ideology through oligarchy of power with development jargon. These anomaly symbols manifest in various aspects, especially in economics, education, law, health and politics; whereas the development paradox is seen in opportunity cost projects and development competition.
\end{abstract}

Keywords : Pathology, anomaly, paradoxes, post-reform, political ethics, hypersemiotics, existentialism-ethical, poststructural. 


\section{PENDAHULUAN}

Penelitian ini dilatari oleh permasalahan etika politik nasional pasca-reformasi di Indonesia ketika persoalan kemanusiaan menjadi masalah dasar atas meruyaknya krisis humanitas yang dibangun secara politis oleh kekuasaan dan kapitalisme. "Kemanusiaan" tampak sebagai aksesoris politik belaka, karena realitas memaksakan secara hegemonik akan sesuatu yang seolah-olah lebih penting dari "kemanusiaan" itu meskipun dibungkus dengan mitos kemanusiaan itu sendiri. Terciptalah suatu keadaan yang boleh disebut sebagai anomalisasi humanisme.

Anomalisasi disebabkan oleh maraknya informasi dari berbagai media yang saling tumpang tindih, sehingga hasil akhirnya jatuh pada realitas semu yang melampaui batas realitasnya (bdk. Sobur, 2001; Sobur, 2017). Agen kapitalisme selain mengontrol media sedemikian rupa, juga mengatur negara sebagai sarana kelancaran kekuasaannya melalui pembangunan infrastruktur hingga membuat etika politik terdistorsi sampai pada taraf yang paling rancu.

Gagalnya etika publik untuk menghasilkan masyarakat humanis dapat dipahami melalui beragam interpretasi yang diberikan pada kata “politik". Politik dianggap sebagai suatu kegiatan yang penuh kedustaan, sehingga menimbulkan keadaan yang mengancam kepunahan demokrasi dan Hak Asasi Manusia (HAM) dengan satu wacana inti, yaitu bahwa politik itu buruk. Wacana tersebut merupakan penanda utama atas kesanksian rakyat terhadap sistem negara/pemerintahan yang semakin melenceng dari asas-asas Negara Kesatuan Republik Indonesia (NKRI). Akibatnya, rakyat tidak peduli dengan kepentingan bersama; dan dari ketakpedulian itu rakyat hendak terkurung dalam penjara intoleran.

Politik dibanjiri oleh salah kaprahnya realisasi sistem demokrasi pascareformasi. Hal ini disebabkan oleh derasnya hujan pasar bebas yang mengguyur kehidupan bangsa Indonesia. Bencana sosial itu tidak semata-mata lahir dengan sendirinya, tetapi direproduksi oleh wacana-wacana publik yang mendominan, seperti halnya iklan-iklan bisnis yang berlebihan dan terus-menerus ditayangkan, sehingga aturan-aturan atau regulasi-regulasi, seperti amandemen UUD 1945 dan informasiinformasi lainnya yang berkaitan dengan kenegaraan kian tertindas. Upaya-upaya dalam bersosialisasi untuk menyentuh beragamnya masyarakat tersendat oleh adanya opini-opini mistis dan magis dari periklanan bisnis.

Efek samping dari sihir bisnis kapitalisme menjadi kesempatan emas bagi kondisi global, sehingga menunjang negara untuk memfasilitasi industrialisme sebagai modal kelancaran bagi penguasa dan penanam modal, sekaligus menjadi kehacuran bagi generasi bangsa. Hal ini yang membuat etika politik pada akhirnya mengalami kecacatan. Negara tidak memberi kesempatan untuk memandirikan warganya, tetapi justru menenggelamkan kesejahteraan dalam bencana besar, dalam banjir yang sukar diatasi bersama.

Ketika mengingat kembali gejolak puncak rakyat Indonesia yang diwakilkan oleh para mahasiswa dan berbuah reformasi, dengan ditandai pengunduran diri Presiden Soeharto pada $21 \mathrm{Mei}$ 1998, membuat para pencetus masa awal reformasi mencanangkan rencana-rencana baru untuk tujuan yang lebih "baik". Mundur lagi pada krisis ekonomi, di mana secara praktis, krisis ekonomi di berbagai belahan dunia kala itu membuat setiap rakyat, baik para kapitalis maupun kaum marjinal seakan merasa jatuh. Jika mengacu pada definisi reformasi secara umum yang berarti perubahan terhadap suatu sistem yang telah ada pada suatu masa, maka sistem yang dimaksud adalah pasca-pemerintahan Presiden Soeharto dan didasari dengan dalil kembali ke UUD 1945 yang rupanya dirasa perlu perubahan pada masa itu. 
Salah satunya adalah keempat amandemen UUD 1945 yang berjalan antara tahun 1999-2002.

Globalisasi dalam pascareformasi yang notabenenya adalah anomalisasi humanisme, di satu sisi dapat diresapi melalui banyaknya pencitraan pada poster caleg di tahun politik, ketimbang adanya caleg yang menyetor dan menyajikan program terbaik sesuai formasi kemerdekaan Indonesia bagi masyarakat di daerah yang akan diwakilinya. Selain itu, dapat diresapi juga melalui banyaknya golput sebagai tanda bawasanya rakyat enggan untuk masuk dan memilih opsi yang telah disediakan oleh panitia penyelenggara pesta demokrasi. Di samping itu, bertumbuhkembangnya pembangunan mengakibatkan matinya kemandirian berbangsa dan berwarga negara. Ini dapat dibuktikan dengan fenomena maraknya potret gedung megah yang mahatinggi, bertambahnya kemacetan yang menopang aksi berebut jalan demi upah yang telah diatur oleh industrialisme, krisis pemuda yang dikendalikan oleh agen kapitalisme, dan lain-lain. Inilah tanda bagi kegagalan pembangunan, di mana pembangunan yang dianggap penting bagi daya saing tingkat global, namun tanpa disadari pembangunan termaksud tidaklah lain merupakan paradoks. Fenomena globalisasi dan hilangnya kepercayaan rakyat akan wakilnya telah cukup menginformasikan, bahwa kemanusiaan perlu dipertanyakan kembali.

Pembahasan mengenai etika politik dan humanisme sebelumnya telah diulas di beberapa penelitian. Rizkiyah (2019) ${ }^{1}$ dalam kajian "Deradikalisasi Keagamaan di Indonesia dalam
Studi Kritis Humanisme Islam Nurcholish Madjid" dimaksudkan untuk mengetahui peluang dan hambatan penerapan deradikalisasi sebagai strategi penanggulangan terorisme di Indonesia dengan menerapkan soft approach (pendekatan lunak). Putera (2017) dengan judul penelitian "Determinisme Teknologi dalam Perspektif Filsafat Teknologi JeanFrançois Lyotard"2 menggambarkan perkembangan teknologi pada abad ke-21 yang telah menimbulkan banyak perdebatan akibat dampak yang dihasilkannya. Putra $(2015)^{3}$ dalam penelitian "Pemikiran Sukarno Tentang Humanisme Ditinjau Dari Filsafat Manusia" menunjukkan adanya penyejuk keringnya konsep humanisme di Indonesia.

Kajian lainnya adalah "Praktik Politik Dinasti pada Pemerintahan Daerah Kabupaten Jombang Ditinjau dari Perspektif Politik Hukum" oleh Prameswari (2015) 4 yang merupaya merumuskan konsepsi demokrasi yang bebas dari korupsi, kolusi dan nepotisme pada pemerintahan daerah guna wujudkan tujuan politik hukum dan cita-cita bangsa Indonesia yang adil, makmur dan sejahtera. Demikian pula penelitian Maharani (2015) dengan judul "Konsep Etika Kepedulian Carol Gilligan dalam Perspektif Filsafat Manusia: Relevansinya Bagi Pemahaman Hubungan Antargender di Indonesia"5 yang mengangkat konsep etika kepedulian sebagai moralitas perempuan yang menggambarkan cara yang khas perempuan dalam bereksistensi dalam relasi antar individu.

Berdasarkan sepintas berbagai patologi politik tersebut, kajian etika politik difungsikan guna memahami strukturasi perpolitikan pascareformasi

\footnotetext{
${ }^{1}$ Rizkiyah, Eva Laila. 2019. Deradikalisasi Keagamaan di Indonesia dalam Studi Kritis Humanisme Islam Nurcholish Madjid. Tesis tidak diterbitkan. Yogyakarta: Universitas Gadjah Mada.

${ }^{2}$ Putera, Ramadi. 2017. Determinisme Teknologi dalam Perspektif Filsafat Teknologi Jean-François Lyotard. Tesis tidak diterbitkan. Yogyakarta: Universitas Gadjah Mada.

${ }^{3}$ Putra, Surya Desismansyah Eka. 2015. Pemikiran Sukarno Tentang Humanisme Ditinjau Dari Filsafat Manusia. Tesis tidak diterbitkan. Yogyakarta: Universitas Gadjah Mada.

${ }^{4}$ Prameswari, Ade Pupi. 2015. Praktik Politik Dinasti pada Pemerintahan Daerah Kabupaten Jombang (Ditinjau dari Perspektif Politik Hukum). Tesis tidak diterbitkan. Yogyakarta: Universitas Gadjah Mada.

${ }^{5}$ Maharani, Septiana Dwiputri. 2015. Konsep Etika Kepedulian Carol Gilligan dalam Perspektif Filsafat Manusia: Relevansinya Bagi Pemahaman Hubungan Antargender di Indonesia. Disertasi tidak diterbitkan. Yogyakarta: Universitas Gadjah Mada.
} 
sebagai penanggulangan krisis moral. Untuk membongkar berbagai patologi perpolitikan yang mengancam moral publik, hipersemiotik-fenomenologis dioperasikan sebagai upaya membuka kran pikiran yang tersumbat oleh banjir mitos/ hoax dan derasnya politik pembangunan yang disponsori oleh dominasi modern dan kapitalisme yang anonimus (atau yang dapat disebut sebagai post-capitalism). Dua permasalahan utama diajukan dalam penelitian ini, yaitu bagaimana (1) bentuk simbol-simbol anomalisasi humanisme dan (2) fenomena paradoks pembangunan dalam etika politik pasca reformasi.

\section{PERDEBATAN TEORETIK}

Teori utama dalam penelitian ini adalah etika politik yang secara lebih spesifik mengaplikasikan teori Eksistensialisme-Etis Levinas, sedangkan metode pembacaan masalah penelitian menggunakan teori hipersemiotika dengan pendekatan fenomenologis. Sebelum masuk dalam rumusan teori Levinas secara konsepsional, perlu terlebih dahulu memahami logika Kantianisme sebagai rujukan dasar bagi kajian etika. Etika secara umum memang kerap dikaitkan dengan urusan moral. Bagi Kant, ${ }^{6}$ moral merupakan kehendak yang baik atau kehendak kebaikan. Pandangan Kant ini dapat dipahami bahwa, bagi siapa saja yang sedang menjalani nasib baik berdasarkan bakat, kekayaan, dan sebagainya, namun tidak didasari oleh kehendak kebaikan, maka itu tidak bisa disebut sebagai sesuatu yang memiliki moralitas. Jika seorang politikus memberi se-berkas uang kepada masyarakat pendukungnya sebagai sesuatu yang disebutnya "kehormatan", di mana itu semua dinyatakan dalam rangka pencapaian citra yang baik, yang tentunya terdapat misi di balik itu semua sebagai strategi politik, maka itu bukanlah kehendak baik.

Dalam pandangan Graham, ${ }^{7}$ Kant melihat bahwa, meskipun seseorang cenderung untuk menyatakan bahwa dalam kasus penyalahgunaan suatu anugerah yang dimilikinya itu dianggap menjadi suatu yang lahir dari kehendak baik, maka semestinya ia harus berpaling pada standar paling dasar mengenai baik-buruk dan benar-salah dalam perilaku atau tindakan. Di samping itu, Kant juga menegaskan bahwa, betapapun orang yang sangat berhati-hati dalam menyusun rencana, mustahil ia bisa menjamin hasilnya.

Jika moralitas dalam pandangan Kant pada intinya berdasar pada apa yang disebutnya sebagai "kehendak yang baik", maka dalam pandangan filsuf lain, Levinas misalnya, menganggap moralitas sebagai respons atau tanggung jawab terhadap subjek yang lain. Artinya, moralitas itu ada dalam diri manusia yang menghendaki dirinya diinterupsi oleh manusia lainnya, tanggung jawab hanya akan terlihat bilamana ia merespons kehadiran sesuatu yang lain di luar dirinya, di mana ia menjalankan upaya dalam memahami keberlainan (alterity) yang hidup di tiap-tiap diri selain dirinya. Pandangan Levinas tentang etika secara implisit merupakan kritik sekaligus revisi terhadap paradigma rasionalitas Kant. Etika dalam pandangan Levinas atau yang dikenal sebagai eksistesialisme-etis, mencakup unsur-unsur humanisme yang terkandung di dalamnya sebagai upaya mengembalikan etikasentris yang kerap kali didominasi oleh berbagai pemikiran-pemikiran yang cenderung egosentris.

Jika ditarik pada urusan politik, maka eksistensi manusia berpolitik pertama-tama dapat ditegaskan melalui pandangan Aristoteles mengenai manusia

\footnotetext{
${ }^{6}$ Kant, Immanuel. 1959. Founndations of The Metaphysics of Morals (Terj. Lewis White Beck). Indianapolis: Bobbs-Merrill Educational Publishing., hlm. 9

${ }^{7}$ Graham, Gordon. 2014. Teori-Teori Etika (Terj. Irfan M Zakkie). Bandung: Nusa Media., hlm. 147
} 
sebagai zoon politikon (makhluk sosial). Bagi Aristoteles, ${ }^{8}$ Tuhan (theos) tidak sosial, karena Tuhan hanya satu dan mencukupi diri dan binatang juga tidak sosial, sebab hanya hidup sesuai dengan insting dan dorongan individualnya masing-masing. Sosial bukan hanya sekedar kerja sama, seperti halnya semut, melainkan juga melakukan kerja sama yang didasarkan pada diskursus rasional bersama, pertimbangan, debat, dan upaya kesadaran kritis lain sebagainya. Jika pandangan Aristoteles demikian, maka pada periode mutakhir Rancière membongkar kecacatan produk atau sistem yang dihasilkan oleh para politisi abad-21. Filsafat moral direalisasikan dengan sangat melenceng dari konsep awal, sehingga membentuk elitisme dalam politik, yakni partisi-partisi dan hirarki sosial dengan nilai higienis dari masing-masing strata. ${ }^{9}$ Rancière membongkar makna politik yang sama sekali berbeda dengan konsepsi awal. Inilah yang membedakan "politik" dengan apa yang disebutnya sebagai "Yang-Politis".

Berdasarkan "Yang-Politis", wakil rakyat tidak dapat mengubah yang diwakilinya, ia hanya dapat mempraktikkan sebagai Yang-Etis, dan dari praktik itulah secara implisit ia dapat merefleksikan atau memberi contoh etika yang baik kepada publik, tanpa harus memaksa yang diwakilinya untuk sesuai dengan kehendaknya. Tanggung jawab kepada publik inilah yang menjadi esensi etika Levinas, di mana secara substantif merujuk pada bagaimana orang semestinya bertanggung jawab atas kehadiran orang lain dalam kehidupan bersama.

Levinas memusatkan studinya pada filsafat, khususnya pada pemikiran Edmund Husserl (1859-1938) dan Henry Bergson (1859-1941) dalam kajian fenomenologi untuk mem-bongkar persoalan-persoalan etik. ${ }^{10}$ Levinas juga melontarkan kritik pada Dasein-nya Heidegger dengan pernyataan mengenai "Ada" yang bukan lagi memusatkan kesadaran pada ego, melainkan "memberi tanggapan (response) atas kehadiran Yang Lain" pada Being. Di samping itu, Levinas turut mengkritisi paradigma modern dengan memperbarui pemikiran Descartes tentang cogito yang berkesadaran pada dirinya tanpa memper-timbangkan kehadiran sesuatu di luar dirinya, sehingga Cogito ergo sum (aku berpikir maka aku Ada) menurut Levinas seharusnya diganti dengan Respondeo ergo sum (aku bertanggungjawab atas liyan maka aku Ada). ${ }^{11}$

Levinas menggunakan istilah "Yang-Sama" (The Same) yang bersinonim dengan Aku, diri personal, ego, atau subjek, yang di dalamnya terdapat muatan pemikiran-pemikiran seperti halnya imajinasi, persepsi, pengetahuan dan/atau gagasan. Sedangkan istilah "Wajah" (face) adalah kenampakan Liyan/Yang-Lain (The Other), atau lebih spesifiknya merujuk pada diri yang lain selain $A k u$. "Wajah" yang dimaksud oleh Levinas tidaklah mengacu pada bagian utama dan depan tubuh, di mana terdapat mata, hidung, dan mulut, seperti yang dipahami secara umum, sebaliknya, "Wajah" merupakan sesuatu yang lebih abstrak namun sangat dalam, yakni keseluruhan cara orang lain memperlihatkan dirinya kepada The Same." Oleh karena "Wajah" merupakan upaya menampakkan diri kepada The Same, maka kenampakan itu tidak pernah total. Selain itu, "Wajah" diungkapkan sebagai entitas yang memiliki sifat ke-tak-berhingga-an atau sebagai Yang-Tak-Terbatas (the infinite). Oleh karena

\footnotetext{
${ }^{8}$ Suseno, Franz Magnis. 2009. Menjadi Manusia: Belajar dari Aristoteles. Yogyakarta: Kanisius., hlm. 30-31

${ }^{9}$ Rancière, Jacques. 2004. The Philosopher and His Poor (Terj. John Drury, Corinne Oster, dan Andrew Parker). Dunham: Duke University Press., hlm. 19

${ }^{10}$ Tjaya, Thomas Hidya. 2011. Empat Esai Etika Politik: Tanggung Jawab Terhadap 'Yang-Lain'dalam Pluralitas—Etika Politik Emmanuel Levinas. Jakarta: Salihara., hlm. 92

${ }^{11}$ Bertens, K. 2014. Filsafat Barat Kontemporer: Prancis (Terj. Mulyono). Jakarta: Gramedia., hlm. 280

${ }^{12}$ Tjaya, Thomas Hidya. 2012. Enigma Wajah Orang Lain: Menggali Pemikiran Emmanuel Levinas. Jakarta: KPG., hlm. 7
} 
sifat tersebut, "Wajah" tidak pernah bisa ditangkap sepenuhnya, tetapi hanya bisa ditafsirkan melalui jejak (trace), dan tafsiran atas siapa dan bagaimanakah "Wajah" itu hanyalah bagian dari pengetahuan atau gagasan atas "Wajah" dalam konteks tertentu. ${ }^{13}$

Dalam memahami ketampakan "Wajah", praktik fenomenologis sangat diperlukan. Bagi Levinas, ${ }^{14}$ dogmatisme dalam bentuk apapun musti ditolak agar objek kesadaran itu dapat menampakkan diri sebagaimana adanya. Itulah alasan fenomenologi sering dipandang sebagai usaha untuk menghidupkan kembali kontak langsung dengan realitas, atau seperti yang sering dirumuskan Husserl sendiri, bahwa fenomenologi sebagai metode musti kembali ke objek-objek itu sendiri (zu den Sachen selbst), dan bukan sesuatu yang telah direduksi dalam pengertian secara objektif atau universal.

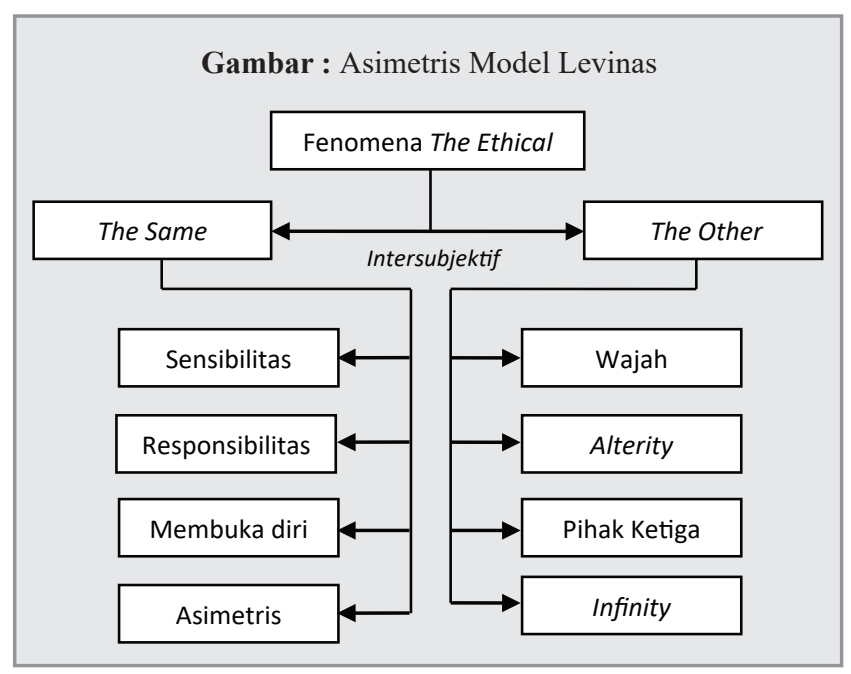

Levinas menunjukkan relasi intersubjektif, di mana subjek ditundukkan dalam hubungannya atas kehadiran subjek lain. 'Tunduk' dimaksudkan sebagai respon terhadap kehadiran orang lain yang tak dikenal. Inilah yang dimaksud oleh Levinas sebagai perjumpaan 'Yang-Etis' (The Ethical).
Dalam hal ini, Levinas memberikan konsep 'asimetris' sebagai peran aktif Yang-Etis. Asimetris merupakan tindakan tanpa balas jasa. Artinya, seseorang bisa membiarkan dirinya untuk dipertanyakan oleh Yang-Lain, namun sebaliknya, seseorang (subjek) tidak boleh menuntut Yang-Lain untuk menyarahkan diri. Melalui peristiwa relasi intersubjektif tersebut, The Ethical menjadi eksis. Tetapi, tidak menutup kemungkinan bahwa bentuk yang tidak etis juga dapat diperoleh melalui peristiwa intersubjektif tertentu lainnya.

Dalam etika intersubjektif, membuka dan menyerahkan diri berarti upaya membiarkan diri untuk dipertanyakan oleh Yang-Lain, dan bukan menutup diri yang sesungguhnya telah dikuasai oleh gagasan atau pengetahuannya sendiri. Tindakan membuka dan menyerahkan diri untuk bersedia dipertanyakan oleh Yang-Lain merupakan bentuk sensibilitas sebagai manusia. Bagi Levinas, ${ }^{15}$ Sang Aku adalah subjek yang dapat 'disentuh' dan mampu menerima pertanyaan dari Yang-Lain. Dengan kata lain, manusia adalah subjek yang sensibel (sensible). Konsep sensi-bilitas mengarah pada subjek yang hidup, dan bukan hanya sekedar pada subjek yang sadar. Artinya, manusia dalam kehidupan tidak hanya berhadapan dengan intensionalitas kesadaran ego, melainkan juga bergesekan langsung dengan sesuatu yang konkret di luar dirinya sebagai bagian dari kehidupannya.

Dalam perjumpaan Yang-Etis, Levinas tidak memberi batas hanya pada relasi antara subjek dengan subjek yang lain yang hanya menyangkut dua pihak saja, tetapi juga melibatkan subjek-subjek yang lain pula, yakni pihak ketiga. Adanya pihak ketiga menunjukkan bahwa, Levinas bertujuan untuk memberikan pandangan The Ethical agar diberlakukan sebagai tanggung jawab yang tidak hanya berhenti pada satu atau sekelompok orang,

\footnotetext{
${ }^{13}$ Ibid., hlm. 10

${ }^{14}$ Levinas, Emmanuel. 1969. Totality and Infinity (Terj. A. Lingis). Pittsburgh: Duquense University Press., hlm. 28

${ }^{15}$ Op.cit. Tjaya, Thomas Hidya. 2012., hlm. 108
} 
tetapi untuk semua orang. Bagi Levinas, ${ }^{16}$ relasi etis ini merupakan kondisi bagi kemungkinan adanya 'keadilan'. Keadilan di sini bukan saja keadilan dalam konsep para filosof positivisme atau pandangan umum dari kaum idealisme, melainkan upaya negasi terhadap nilai-nilai yang sangat me-mungkinkan bagi ketersumbatan responsibilitas terhadap "Others", akibat banyaknya asumsi yang saling tumpang-tindih satu dengan yang lain. Asumsi-asumsi tersebut dihasilkan oleh pengetahuan yang sifatnya objektif, sedangkan tugas dari etika agar dapat eksis yaitu dengan menangguhkan pengetahuan tersebut berdasarkan otentisitas subjek dalam menangkap, mengamati serta mencermati sesuatu sebagai fenomenanya.

Berdasarkan uraian beberapa konsep dan kerangka pikir teoretis, pemikiran Levinas mencakup bidang filsafat fenomenologi, eksis-tensialisme, dan etika. Dari fenomena-fenomena yang tampak, dapat disadari bahwa fenomena The Ethical yaitu, The Same (Aku) yang mampu memberikan respons dan membuka diri terhadap orang lain, menghargai keberlainan (alterity) atau keunikannya, tidak menuntut balas jasa terhadap-nya, dan memahami bawasanya orang lain tidak hanya sesuatu yang berada dalam anggapan atau gagasan atau bahkan sesuatu yang diobjek-tivikasikan, melainkan suatu infinity.

Masuk pada teori berikutnya. Hiper-semiotika dipilih berdasarkan sistem penandaan yang melampaui struktur penandaan sebelumnya. Jika dalam kerangka pikir semiotika strukturalis terdapat konsep petanda, maka dalam hiper-semiotika konsep petanda sama sekali kosong, sebab isi dari petanda sebetulnya adalah penanda. Dengan demikian, yang ada hanyalah rantai penanda. Kekosongan petanda ditunjukkan oleh para pemikir postrukturalis, seperti Derrida, Barthes, Eco, Kristeva, Baudrillard, dan seterus-nya. Jika semiotika dalam tradisi strukturalisme adalah ilmu atau kajian tentang tanda, maka dalam tradisi Derridean adalah ilmu yang membongkar kepastian penandaan, maka dalam tradisi Barthesian adalah ilmu yang membedah mitos-mitos budaya massa, maka dalam konsep Eco adalah ilmu tentang kedustaan, maka dalam konsep Kristeva adalah ilmu tentang mozaik kutipan-kutipan, dan maka dalam konsep Baudrillard adalah ilmu tentang simulasi dan pengkopian terus-menerus.

Hipersemiotika hadir dalam rangka menghancurkan ketunggalan makna yang berpihak pada objektivitas, universalitas, dan totalitas. Di samping itu, hipersemiotika menolak tradisi struktural. Dalam hal ini, hipersemiotika bukan berarti anti struktur, melainkan memiliki struktur namun dengan struktur yang fleksibel dan dinamis. Hal ini dapat dipahami melalui karakteristiknya yang mengedepankan subjek-tivitas dan parsialitas. Dalam konteks ini, ketakterbatasan makna sangat dimungkinkan, seperti halnya dekonstruksi dalam konsep Derrida. Dekonstruksi bersifat differance. Bagi Derrida, ${ }^{17}$ differance berupaya menjelaskan sebuah proses permainan bebas penanda dengan melepaskan diri dari determinasi dan fondasi-fondasi metafisik. Artinya, sebuah objek dibedakan nilainya dari objek sejenis melalui bentuk dan makna sosial yang dikandungnya. Pembedaan yang dimaksudkan tidaklah lain berunsur pada konsep oposisi biner, sebagaimana suatu prinsip pertentangan di antara dua istilah, seperti: maskulin/feminin, Barat/Timur, kanan/ kiri, dan sebagainya.

Selain membedakan, differance juga bersifat menunda. Oleh sebab itu, makna dalam suatu tanda menjadi tidak pasti karena adanya ruang "kemungkinan-kemungkinan" tanpa akhir. Di samping dekonstruksi Derrida, Barthes memberi jalan alternatif lain dengan apa yang disebutnya

\footnotetext{
${ }^{16}$ Ibid., hlm. 105

${ }^{17}$ Piliang, Yasraf Amir. 2003. Hipersemiotika: Tafsir Cultural Studies Atas Matinya Makna. Bandung: Jalasutra., hlm. 246
} 
sebagai mitologi, yakni diskursus tentang mitos. Lain halnya dengan mitos dalam pandangan umum, bagi Barthes, ${ }^{18}$ mitos adalah a type of speech; sebuah pembicaraan atau wicara yang disampaikan lewat wacana (discourse). Mitos bukanlah suatu objek, konsep, atau gagasan, melainkan suatu bentuk (a form) atau suatu mode pertandaan. Artinya, segala hal menyangkut tanda memiliki potensi besar sebagai mitos, sejauh ia diterjemahkan dalam suatu wacana. Teks beralih menjadi mitos akibat selera produsen bagi kepentingannya.

Sejalan dengan pemikiran Derrida dan Barthes, semiotikus postruktural lain turut berkontribusi pada hipersemiotika. Dalam hal ini Eco menunjukkan bahwa berbahasa adalah alat berbohong atau berdusta. Bagi Eco, ${ }^{19}$ jika sesuatu tidak dapat digunakan untuk mengekspresikan kebohongan, maka sesuatu itu juga tidak dapat digunakan untuk 'mengatakan' apa-apa. Artinya, tanda sebagai wakil tentu tidak mentotalisasi kehadiran sesuatu yang sedang diwakilinya. Inilah substansi "dusta" dalam linguistik secara esensial. Wacana tidak harus dibenarkan begitu saja, tetapi perlu diperiksa apa yang menopang di balik wacana itu. Sementara dalam pandangan Kristeva, ${ }^{20}$ teks (tanda) hanya akan ada bilamana ditopang oleh teks yang lain yang berada di luar teks tersebut. Dan dalam pengertian Baudrillard, tanda dipandang sebagai simulasi, simulakra, dan simulakrum yang berakhir pada realitas semu, di mana tanda dapat menggantikan realitas.

\section{METODE}

Penelitian ini merupakan penelitian kualitatif yang dimaksudkan untuk untuk mengeksplorasi dan memahami makna, baik oleh sejumlah individu maupun oleh sekelompok orang menganggap makna tersebut berasal dari masalah sosial atau masalah kemanusiaan. ${ }^{21}$ Bentuk penelitian ini mensyaratkan penerapan cara pandang penelitian yang bergaya induktif, berfokus pada makna individual, dan mener-jemahkan kompleksitas suatu persoalan. Peneliti-an kualitatif mengandalkan manusia sebagai alat penelitian di mana subjek peneliti sebagai instru-men utama, sehingga terjadi interaksi secara langsung di antaranya, serta lebih mementingkan proses daripada hasil. ${ }^{22}$

Fenomenologi dipilih sebagai pendekatan analisis. Dalam pendekatan ini, peneliti bebas menangkap fenomena sesuai subjektivitasnya. Bagi Husserl, ${ }^{23}$ fenomenologi merupakan praktik dalam 'menangkap' sesuatu dari sekian banyaknya sesuatu yang tampak. 'Menangkap' yang dimaksud yaitu, bagaimana seseorang bisa menganggap sesuatu itu lebih penting dari sesuatu yang tampak lainnya. Tidak menutup kemungkinan bahwa peran sesuatu yang tampak lainnya itu tidak kalah pentingnya, akan tetapi sesuatu yang ditangkap itu lebih dipentingkan, karena penangkapan tersebut senantiasa berkaitan langsung dengan kesadaran si penangkap yang berdasarkan pengalaman subjektivitasnya.

Sumber data penelitian merupakan sumber dimana data dapat diperoleh, sementara data

\footnotetext{
${ }_{18}$ Barthes, Roland. 2010. Membedah Mitos-Mitos Budaya Massa (Terj. Ikramullah Mahyuddin). Yogyakarta: Jalasutra., hlm. 295

${ }^{19}$ Eco, Umberto. 2015. Teori Semiotika: Signifikasi Komunikasi, Teori Kode, serta Teori Produksi Tanda (Terj. Inyiak Ridwan Muzir). Yogyakarta: Kreasi Wacana., hlm. 7

${ }^{20}$ Nöth, Winfried. 2006. Semiotik (Terj. Dharmajo, dkk.). Surabaya: Airlangga University Press., hlm. 328

${ }^{21}$ Creswell, John W. 2014. Research Design: Pendekatan Kualitatif, Kuantitatif, dan Mixed (Terj. Achmad Fawaid). Yogyakarta: Pustaka Pelajar., hlm. 4

${ }^{22}$ Sugiyono. 2019. Metode Penelitian Kuantitatif, Kualitatif, dan R\&D. Bandung: Alfabeta., hlm. 1

${ }^{23}$ Op.cit. Tjaya, Thomas Hidya. 2012., hlm. 24
} 
penelitian adalah bahan yang dikelola dan dianalisis. Berdasarkan kerangka pikir penelitian, sumber data dalam penelitian ini yaitu dokumen publik berbasis komputer (database terkompu-terisasi) yang mencakup berita-berita atau fakta-fakta politik yang dimuat dalam berbagai surat kabar online terpercaya. Sebagai tambahan data untuk membuktikan fenomena pembangunan pasca reformasi, peneliti memasukkan beberapa hasil wawancara dengan pihak-pihak yang terkait dengan masa orde baru hingga reformasi. Sedangkan data dalam penelitian berupa teks-teks yang ada dalam sumber data sesuai masalah penelitian, yakni simbol-simbol humanisme, fenomena pembangunan, serta efek kinerja politik kekuasaan pasca reformasi.

Teknik pengumpulan data yang digunakan yaitu teknik kepustakaan atau dokumentasi dengan strategi pembacaan fenomenologis, sesuai dengan pendekatan penelitian yang digunakan. Teknik kepustakaan atau dokumentasi dipilih berdasarkan kaidah-kaidah penelitian kualitatif. Sedangkan pada teknik analisis data, menggunakan teknik deskriptif analitik. Teknik tersebut dapat dipahami sebagai teknik yang dilakukan dengan cara mendeskripsikan fakta-fakta sesuai kajian yang digunakan dalam analisis. Berdasar-kan hal tersebut langkah-langkah dalam teknik deskriptif analisis dilakukan, yaitu: (1) menelaah kembali data sesuai dengan kajian atau studi etika politik secara semiotis dan fenomenologis; (2) menganalisis data dengan memberikan inter-pretasi pada data secara semiotis dan fenomeno-logis sesuai dengan rumusan masalah dan tujuan penelitian; dan (3) menarik simpulan atas analisis data pada bagian pembahasan.

\section{HASIL DAN PEMBAHASAN}

Pasca reformasi menjadi era, di mana kondisi di dalamnya memuat patologi-patologi politik yang pada pokoknya adalah anomalisasi humanisme. Anomali yang dikemas melalui ideologi-ideologi yang tak kasat mata bagi pandangan umum ini, terusmenerus bertumbuh-kembang dan menyeluruh ke segala aspek, mulai dari ekonomi, pendidikan, hukum, sampai kesehatan, dan dari kesemua aspek tersebut, faktor utamanya bersumber dari aspek politik.

Politik sebagai unsur utama kenegaraan tidak lagi memihak pada kepentingan bersama sebagaimana mustinya, tetapi kepentingan bersama tersebut ditentukan oleh kekuasaan yang terus mengikis mobilitas sosial kemanusisaan. Penyelewengan demi penyelewengan yang tengah terjadi merupakan jejak atas ketersingkapan wajah demokrasi Indonesia. Reformasi yang dimaksudkan dalam rangka mewujudkan kesejahteraan bersama, menegakkan keadilan, serta memperbaiki kehidupan berbangsa dan bernegara sesuai dengan asas-asas Negara Kesatuan Republik Indonesia (NKRI), justru dalam realitasnya melenceng jauh dari yang diharapkan.

Banyaknya fakta dan fenomena-fenomena yang menunjukkan penyimpangan merupakan efek yang dihasilkan oleh buruknya regulasi ruling class. Tren wacana global menjadi pedoman yang diacu oleh para regulator tanpa peduli terhadap etika bernegara, yang pada akhirnya publik jatuh dalam lingkaran im-moralitas. Keterpurukan dalam belenggu ini mengalami pembiaran sampai pada taraf yang paling rancu dan menyebabkan otentisitas sosial-budaya di Indonesia menjadi terdistorsi oleh dominasi modern, di mana kapitalisasi secara hegemonis telah mengakar, sehingga menjadikan masyarakat bermental konsumeristik, yang tentunya sulit dan sukar untuk berdikari.

Dengan demikian pembangunan negara, baik secara fisik maupun sistematik, hanya akan mempersempit jarak tempuh ke arah pembangunan yang paradoks. Pembangunan demi kemajuan 
serta kelancaran hidup manusia hanya termaktub secara tekstual saja, sebab pada realitasnya, pembangunan secara fisik melahirkan banyak polusi yang kian mencemari lingkungan hidup manusia, sementara pembangunan secara sistematik semakin membelah jarak antar manusia dalam keharmonisan berwarganegara dengan menyudutkan masyarakat tradisional dan memarjinalisasi kalangan kelas bawah.

Untuk mempertebal kritik terhadap kondisi politik pascareformasi, anomalisasi humanisme dibongkar melalui pembacaan hipersemiotika, sementara pada paradoks pembangunan diurai berdasarkan diskursus fenomenologi. Kedua identifikasi tersebut tetap dalam kajian etika politik berdasarkan implementasi dari kebijakankebijakan yang fatal. Pada bagian pertama dibongkar persoalan mengenai bentuk simbol-simbol anomalisasi humanisme yang meliputi beberapa sektor, yakni: ekonomi, pendidikan, hukum, kesehatan, dan politik. Sementara pada bagian selanjutnya diuraikan fenomena-fenomena paradoks pembangunan yang meliputi yaitu fenomena proyek opportunity cost, dan fenomena kompetisi pembangunan; rumah sakit versus pabrik.

\section{SIMBOL ANOMALISASI HUMANISME SEKTOR EKONOMI}

Dalam dekade terakhir ini, kapitalisme mengemas produk-produknya dengan khas modernitas yang berkembang dalam sektor informasi dan teknologi, utamanya di bidang ekonomi dan perbankan. Hal ini dapat disimak dalam kebijakan Bank Indonesia (BI). ${ }^{24}$ Dominasi secara hegemonis dalam bingkai modernitas terpampang jelas melalui kebijakan sistem pembayaran. Kebijakan dengan program berbasis teknologi modern seperti e-money dan sebagainya secara implisit ditujukan kepada pihak yang dapat saling menguntungkan yakni para pemilik modal atau kapitalisme. Masyarakat kelas bawah yang hanya membutuhkan sandang (pakaian), pangan (makanan), papan (tempat tinggal) tentu tidak memerlukan kebijakan sistem pembayaran serba elektronis yang demikian.

Jika keberagaman masyarakat di Indonesia memang diakui, maka kebijakan-kebijakan sistem pembayaran semestinya dapat berjalan secara dinamis. Masyarakat yang dapat diposisikan sebagai pembeli atau konsumen, dalam hal ini tidak dapat disamaratakan begitu saja, tetapi musti diperhatikan, utamanya bagi liyan di luar konsepsi modern agar dipenuhi hak-haknya. Differance tersebut secara semiotis dapat dipahami bahwa, ada ketidakadilan dalam kebijakan sistem pembayaran yang telah diketuk dan ditetapkan. Kapitalisme tengah menjual produk-produk modern yang alih-alih praktis dan membantu stabilitas sosial serta memudahkan kegiatan bertransaksi. Akan tetapi, untuk memahami logika permasalahan, yang perlu diperhatikan yaitu, masyarakat Indonesia yang kiranya tidak dapat memproduksi sendiri bahanbahan modern, serta masyarakat multikultur yang masih berpegang teguh pada tradisi budaya adat. Hal ini yang sangat beroposisi dengan sistem pembayaran yang membesitkan modernitas. Dekonstruksi ini dapat ditegaskan lebih lanjut dalam sila kelima Pancasila "Keadilan Sosial bagi Seluruh Rakyat Indonesia”. Dengan demikian, jejak-jejak kapitalisme terbongkar.

\section{SEKTOR PENDIDIKAN}

Regulasi tentang kurikulum pendidikan dari

\footnotetext{
${ }^{24}$ Direktorat Akunting dan Sistem Pembayaran \& Direktorat Pengedaran Uang. Laporan Sistem Pembayaran dan Pengedaran Uang. Diterbitkan oleh Bank Indonesia (BI) pada tahun 2008 dan 2009.
} 
masa ke masa dapat saja dipahami sebagai tanda kemajuan, sejauh regulasi tersebut berjalan efektif dan efisien. Sebaliknya, jika kurikulum yang dicanangkan telah membentur realitas masyarakat, maka ini justru membangun ke-munduran bangsa melalui pemaksaan sistem pada sektor pendidikan yang merupakan instrumen utama garis keturunan penerus bangsa. Sektor pendidikan pun sama halnya dengan sektor ekonomi, yakni mengacu pada modernisme. Hal yang paling tampak dalam warna modernitas yaitu teknis pendidikan yang bermula dilaksana-kan melalui media fisik (lembar kertas), kini bergeser ke media elektronik dengan berbasis komputer. Dalam tahap akhir sekolah, peserta didik diwajibkan untuk mengikuti Ujian Nasional Berbasis Komputer (UNBK).

Teknologi modern memang dimaksudkan agar peserta didik mampu berkompetisi secara global, akan tetapi bagaimana jadinya apabila negosiasi bocoran saat UN masih diperdagang-kan. Bocornya naskah soal UN sebagai dokumen negara menimbulkan kekhawatiran pada generasi bangsa dan tunas bangsa berikutnya, serta kecemasan bagi kerusakan moralitas publik. Dalam kasus yang dimuat oleh CNN Indonesia, ${ }^{25}$ bocornya soal Ujian Sekolah Berstandar Nasional (USBN) diperoleh dari sejumlah Lembaga Bimbingan Belajar (LBB). Kasus tersebut menjadu bentuk atas keambrukan moralitas politik untuk menumbuhkan kecerdasan berbangsa dan bernegara, khususnya pada generasi bangsa dalam bidang pendidikan, sebagaimana yang terdiktum di dalam UUD 1945 tepatnya pada pasal 31 ayat (1) yang menyebutkan bahwa setiap warga Negara berhak mendapat pendidik-an, dan ayat (3) menegaskan bahwa Pemerintah mengusahakan dan menyelenggarakan satu sistem pendidikan nasional yang meningkatkan keimanan dan ketakwaan serta akhlak mulia dalam rangka mencerdaskan kehidupan bangsa yang diatur dengan undang-undang.

\section{SEKTOR HUKUM}

Indonesia pada dasarnya merupakan negara "rechtsstaat", atau yang dikenal dengan negara hukum, dan bukan negara yang berlandaskan kekuasaan (machtstaat). Namun demikian, tidak jarang bawasanya kekuasaan karap kali mendompleng bahkan menunggangi urusan hukum, meski dalam logika sederhananya, keduanya saling berkait satu sama lain; hukum memerlukan kekuasaan sebagai subjek pelaksana, sementara kekuasaan nantinya hendak dibatasi oleh hukum. Permasalahan di sektor hukum tidak jauh dari urusan bisnis atau proyek yang tentunya dioperasikan oleh kekuasaan. Sebagai bukti atas hukum yang tidak lagi menduduki peri keadilan, salah satunya dapat dipahami melalui kasus penyiraman air keras terhadap penyidik Komisi Pemberantasan Korupsi (KPK), Novel Baswedan yang dalam penyelesaiannya menuai tanda tanya besar. ${ }^{26}$

Kejanggalan kasus Novel dapat dipahami melalui perbandingan dengan kasus-kasus lain yang tidak sebanding, di mana secara semiotis menunjukkan signifikasi bahwa tidak ada ketegakan hukum di negara rechtsstaat. Hal ini bukan saja mengenai penyerangan seseorang begitu saja, melainkan juga figur penyidik KPK yang berperan dalam pemberantasan tindak korupsi di tanah air. Respect for law sebagai asas taat dan hormat pada hukum, serta equality before the law sebagai prinsip

\footnotetext{
${ }^{25} \mathrm{https}$ //www.cnnindonesia.com/nasional/20180404193528-20-288304/soal-usbn-2018-bocor-di-sejumlah-tempat-bimbel

${ }^{26}$ Dimuat oleh beberapa media, TribunNews dan Kompas: https://www.tribunnews.com/metropolitan/2020/06/13/ penyerangnya-hanya-dituntut-1-tahun-penjara-novel-persidangan-berjalan-aneh-janggal-dan-lucu dan https://www.kompas.com/tren/read/2020/06/16/184700265/membandingkan-tuntutan-hukum-pada-kasus-novel-baswedandan-kasus-lainnya?page=all
} 
bahwa setiap orang mempunyai kedudukan dan hak yang sama di hadapan hukum, termasuk juga pihak penguasa dan aparat penegak hukum, dengan demikian justru hanya menjadi pepatah yang hendak mematahkan supremasi hukum yang semestinya merupakan syarat mutlak bagi negara hukum. Dari hal tersebut, keadilan adalah mitos. Keadilan hanyalah atas nama dari abuse of power atau penyalahgunaan kekuasaan dengan berbagai kepentingan yang tampak seakan berlandaskan peraturan serta dasar hukum secara konstitusional, yang seolah-olah mewakili kesejahteraan umum.

\section{SEKTOR KESEHATAN}

"Setiap orang berhak hidup sejahtera lahir dan batin, bertempat tinggal dan mendapatkan lingkungan hidup yang baik dan sehat serta berhak memperoleh pelayanan kesehatan." Begitulah bunyi pasal 28 huruf H ayat (1) UUD 1945. Masalahnya, realitas berpaling dari prinsip tersebut. Kembali naiknya BPJS Kesehatan yang sebelumnya dibatalkan karena gugatan dari Komunitas Pasien Cuci Darah Indonesia (KPCDI) atas Perpres Nomor 75 tentang Jaminan Kesehatan, mengakibatkan sektor kesehatan yang pada mulanya dimaksudkan sebagai upaya untuk memicu kesejahteraan masyarakat dalam meminimalisir wabah atau penyakit bagi setiap penderita, justru menjadi wajah buruk dari negara penuh ketidakadilan dan anomali humanitas. Naiknya BPJS pada dasarnya mencakup urusan ekonomi dan hukum yang kerap terdistorsi.

Di samping kenaikan BPJS, kasus lain datang dari keterangan perwakilan UNICEF untuk Indonesia, Debora Comini, ${ }^{27}$ bahwa hasil riset menyatakan ada sekitar 2 juta anak mengalami gizi buruk dan lebih dari 7 juta anak di bawah usia lima tahun (balita) mengalami stanting. Jika sejak di dalam kandungan saja sudah bermasalah, maka itu berpotensi besar bagi masalah gizi sebagai asupan kecerdasannya. Itu sebabnya, indeks pendidikan mengalami kemerosotan. Kesehat-an yang mustinya menjadi basis dari kemajuan suatu bangsa, pada nyatanya dihalangi oleh buruknya kebijakan yang memaksakan anak untuk tetap tersenyum tanpa peduli kondisi gizi yang semakin memburuk, kondisi di mana hak anak untuk sehat sebagai modal kelancaran berpikir dalam menempuh jenjang pendidikan, menjadi suatu kedaruratan yang sengaja diwajar-kan dan tidak lebih penting dari kepentingan tersendiri.

\section{SEKTOR POLITIK}

Permasalahan pada aspek politik adalah permasalahan inti dalam setiap sektor. Pasca reformasi tidak lagi menjadi poin penting bagi hadirnya kondisi yang diharapkan, tetapi justru menjadi kekacauan yang semakin melejit dalam berbagai hal, mulai dari ekonomi, pendidikan, hukum, kesehatan, dan bidang-bidang lainnya yang tersingkap dalam berbagai fenomena keganjilan negara. Permasalahannya di sini adalah, apa titik temu yang melatari masalah tersebut, dan bagaimana titik temu itu bermula sebagai include atas segala perkara yang terus-menerus beranakpinak. Secara semiotis, pusat permasalahan politik, dapat ditemukan dalam sistem pemilihan umum (PEMILU).

Usangnya presidential threshold pada pilpres 2019 bukan suatu asumsi belaka, melainkan fakta yang ada. Presidential threshold pada dasarnya merupakan permasalahan secara teknis, di mana pokok perkara yang substansial ada pada sistem pemilihan yang basisnya adalah popular vote atau

\footnotetext{
${ }^{27} \mathrm{https}$ //gaya.tempo.co/read/1361602/unicef-soroti-kasus-gizi-buruk-di-indonesia-apa-masalahnya/full\&view= $\mathrm{ok}$ (diakses pada Minggu, 5 Juli 2020, 20.11 WIB)
} 
suara terbanyak. Sistem pemilihan popular vote yang telah berlangsung lebih dari satu dekade ini perlu dipertimbangkan kembali. Pemilihan kandidat berdasarkan suara terbanyak di satu pihak memang menawarkan unsur demokratis, namun di lain pihak unsur tersebut justru menjadi suatu hal yang me-mungkinkan berbaliknya arah demokrasi menuju blunder. Perolehan suara terbanyak menunjukkan bahwa kuantifikasi kualitas lebih dipentingkan ketimbang kualifikasi kuantitas.

Dapat diketahui bersama bahwa pada sistem popular vote, seluruh rakyat mempunyai hak pilih yang sama. Kesetaraan hak dalam persoalan ini seolah tampak merepresentasikan upaya dalam mewujudkan demokrasi. Namun jika ditelusuri lebih tajam, maka suara di antara tokoh masyarakat dan narapidana koruptor memiliki nilai yang sama. Secara rasional, kesamarataan suara yang demikian justru menjadi patologi yang meringkus dinamika demokrasi. Di samping itu, patologi tersebut mengakibatkan sistem politik kehilangan alat dalam memfilter. Jika alat untuk memfilter seorang pemimpin bangsa saja tidak punya, maka dapat dipastikan bahwa regulasi-regulasi yang dihasilkan oleh pemimpin yang terpilih sangatlah jauh dari kejernihan demokrasi, sehingga tonggak keadilan pun patah akibat keruhnya air yang melibas dan menggerogoti fondasi keadilan bagi seluruh rakyat Indonesia.

Dengan demikian, Kontestasi pilpres yang semula diharapkan sebagai ajang pesta rakyat secara demokratis dalam maksud dan tujuan untuk memperbaiki bangsa dan negara, kini harus berakhir sebagai peti rakyat, di mana hak dalam berdemokrasi terkubur secara paksa, sehingga yang ada hanyalah belenggu penuh kebencian dan mala petaka. Kebenaran yang didasarkan pada kuantitas tanpa peduli bagaimana kualitas-nya, hanya akan menciptakan kesenjangan masal.

\section{PARADOKS PEMBANGUNAN PROYEK OPPORTUNITY COST}

Pembangunan di satu pihak memang diperlukan, namun di lain pihak, pembangunan yang terus-menerus dicanangkan dan semakin berlebih tentu menimbulkan perkara yang fatal hingga menjalar ke persoalan moral dan humanisme. Seperti pada kasus yang membentur UU Nomor 41 Tahun 2009 Tentang Perlindungan Lahan Pertanian Pangan Berkelanjutan. ${ }^{28}$ Proyek nasional mengakibatkan lahan pertanian produktif menyusut. Proyek termaksud, antara lain pembangunan Bandarudara Internasional Jawa Barat (BIJB) Kertajati di Majalengka, pem-bangunan jalan tol baru Sukabumi-Bandung (Tol Cisumdawu dan Tol Cigatas), dan Pelabuhan Patimban di Subang yang diprediksi menghabiskan lahan sebanyak 2.000 hektare.

Pembangunan tidak hanya berhenti pada konversi lahan secara fisik, tetapi juga mengkonversi subjek secara ideologis. Pasalnya, jika pembangunan terselesaikan, maka kegiatan ekonomi bertumbuh di wilayah termaksud. Artinya, itu menggusur petani secara hegemonik. Petani di sini bukan hanya dipahami sebagai subjek secara fisik, tetapi juga subjek secara mental. Sarana dibangun untuk sesuatu yang menempatinya. Bandara tentu untuk pesawat, bukan tempat untuk menggiling padi. Jalan tol untuk mobil, bukan untuk menanam padi. Pelabuhan untuk kapal, dan bukan tempat

\footnotetext{
${ }^{28} \mathrm{https} / /$ www.cnnindonesia.com/ekonomi/20180516204148-532-298791/pengamat-defisit-apbn-era-jokowi-lebih-besar-dari-sby diakses pada Kamis, 17 Mei 2018, 11:24 WIB. Lihat: Proyek Tol Sukabumi-Bandung Korbankan Lahan Produktif, di https:// nasional.republika.co.id/berita/pudiha383/proyek-tol-sukabumibandung-korbankan-lahan-produktif diakses Selasa 9 Juli 2019, 18:55 WIB; dan Imbas Banyaknya Proyek Nasional di Jabar, Lahan Pertanian Menyusut, di https://jabar.sindonews. com/read/5666/1/imbas-banyaknya-proyek-nasional-di-jabar-lahan-pertanian-menyusut-1552467785 diakses pada Rabu, 13 Maret 2019, 16:45 WIB.
} 
irigasi. Sarana-sarana itu tidak diciptakan sebagai fasilitas bagi pertanian yang dapat menghasilkan pangan secara mandiri. Jikalau sarana-sarana tersebut dapat menghasilkan pangan dalam sistem yang lain, ekspor misalnya, maka tiap-tiap individu pun musti membayar sistem itu dengan nilai tukar yang ditentukan.

Individu yang otonom dengan segala upaya kemandiriannya demi mendukung kesejahteraan bersama, pada akhirnya tergerus oleh jeratan rantai kapital. Rantai yang memanifestasikan diri sebagai rantai emas; menyulap sawah dan ladang menjadi bangunan-bangunan bermandikan cahaya, lalu menyihir kebutuhan menjadi keinginan. Kapitalisme merampok emas dan menggantikannya dengan rantai sistem yang terstruktur. Negara menyediakan sarana bagi industri kapital yang terusmenerus memasok peralatan kerja. Terminologi pembangunan dalam opportunity cost pada ujungnya merobek jarak antara yang kaya dan yang miskin, menjadikan jarak tersebut semakin jauh, dan tentu hal ini turut mendukung dan meningkatkan kesenjangan.

\section{KOMPETISI PEMBANGUNAN: RUMAH SAKIT VERSUS PABRIK}

Pertumbuhan rumah sakit (RS) dan industri semakin berkembang dan meningkat. Hal ini mengundang tanda tanya besar untuk menelusuri apa dan bagaimana respon Menteri Negara Lingkungan Hidup dalam menetapkan keputusannya, juga Bapedal dalam hasil analisis mengenai dampak lingkungan (amdal). Indeks Standar
Pencemar Udara (ISPU) di Indonesia pada skala internasional masuk dalam kategori buruk. ${ }^{29}$ Perlu dicermati bukan mengenai mana yang lebih unggul di antara keduanya, bukan pula mana yang lebih diperhatikan, melainkan terjadinya jejak (trace) atas pembangunan yang paradoksal ini terbaca secara gamblang. Pembangunan yang dimaksudkan sebagai upaya untuk merealisasikan keunggulan suatu negara serta menunjukkan kemajuan berbangsa, ternyata memberi realitas yang justru sebaliknya.

Pada mulanya bercocok tanam untuk kebutuhan dasar manusia, kemudian menghendaki percepatan pangan dengan melahirkan dunia industri sebagai langkah mencipta alat produksi untuk membekali kinerja bercocok tanam, hingga berkembang pada sektor-sektor lain yang menawarkan rekayasa kimia untuk menunjang percepatan, dan dari sana diperlukan pembangunan-pembangunan sebagai akses utama, yang mana juga memberi lampu hijau pada lalu lintas bidang jasa untuk sarana kelancaran transaksi dalam negosiasi alat-alat serta bahan-bahan yang diperlukan dalam suatu produksi. Dengan demikian, bergeserlah fokus perhatian dari basic needs ke pembangunan.

Orang sibuk dengan keperluan-keperluan lain. Mulai pembangunan pabrik dengan wajah pertumbuhan ekonomi, sampai pembangunan rumah sakit sebagai aksi dari kepedulian dengan memasang wajah kemanusiaan. Pada akhirnya pembangunan diutamakan dan produksi ditinggalkan. Jika pabrik dibangun sebagai alasan pembangunan rumah sakit untuk memberi penawar racun yang dihasilkan dari berbagai polusi, maka menghentikan suatu pembangunan bukanlah suatu perkara besar,

\footnotetext{
${ }^{29} \mathrm{http}$ ://www.cets-uii.org/BML/Udara/ISPU/ISPU\%20(Indeks\%20Standar\%20Pencemar\%20Udara).htm | https://www.aircheckr.com/help-and-guides/air-quality-index | Belum Update, Indonesia Diminta Ikuti Standar Ukuran Polusi Udara Dunia. https://www.suara.com/news/2019/06/28/182245/belum-update-indonesia-diminta-ikuti-standarukuran-polusi-udara-dunia\#: : text=Ia\%20menyebut $\% 20$ US $\% 20 \mathrm{AQI} \% 20$ memiliki,m\%C2\%B3\%20ke\%20atas $\% 20$ (berbahaya). (diakses Jumat, 28 Juni 2019, 18.22 WIB) | PSBB Hari ke-11, AirVisual: Udara Jakarta Masuk 5 Kota Tidak Sehat di Dunia. https://oto.detik.com/berita/d-4983414/psbb-hari-ke-11-airvisual-udara-jakarta-masuk-5-kota-tidak-sehatdi-dunia (diakses Senin, 20 April 2020, 10.28 WIB)
} 
sebab dengan terbebasnya manusia dari segala macam polusi tentu kesehatan jauh dari gangguan. Dengan demikian, orang tidak perlu bersusah payah mendapat banyak uang untuk berobat karena dampak polusi, sebab ia dapat bernafas lega dengan menghirup udara segar, di samping kebutuhan dasarnya yang telah terpenuhi.

\section{KESIMPULAN}

Temuan penelitian ini mencakup bentuk simbolsimbol anomalisasi humanisme dalam etika politik pasca reformasi yang mewujud ke berbagai sektor, yaitu (a) sektor ekonomi sebagai simbol yang merepresentasikan ambruknya kesejahteraan, (b) sektor pendidikan sebagai simbol yang merepresentasikan kegagalan dalam meningkatkan kecerdasan bangsa, (c) sektor hukum sebagai simbol yang merepresentasikan hilangnya keadilan, (d) sektor kesehatan sebagai simbol yang merepresentasikan berbagai penyakit yang terus meningkat, dan (e) sektor politik sebagai simbol yang merepresentasikan kepalsuan bernegara penuh manipulatif yang mengarah pada pemerintahan otoritarian, totaliter, dan feodal.

Penelitian ini juga menemukan fenomena paradoks pembangunan dalam etika politik pasca reformasi, antara lain (a) proyek opportunity cost sebagai fenomena yang menguraikan tentang sinyal kepunahan tanggung jawab negara terhadap keotentikan Indonesia dalam hal sumber daya alam, khususnya pada bidang pertanian dan (b) kompetisi pembangunan yang mempertentangkan rumah sakit versus pabrik sebagai fenomena yang menunjukkan paradoks pembangunan pada ranah industri farmasi dan manufaktur melalui rivalitasnya yang sama sekali tidak memihak pada kesejahteraan bersama, baik dalam hal kesehatan maupun ekonomi.

\section{DAFTAR PUSTAKA}

Barthes, Roland. 2010. Membedah Mitos-Mitos Budaya Massa (Terj. Ikramullah Mahyuddin). Yogyakarta: Jalasutra.

Berger, Arthur Asa. 2015. Pengantar Semiotika:

Tanda-Tanda dalam Kebudayaan Kontemporer (Terj. Muhammad Yahya). Yogyakarta: Tiara Wacana.

Bertens, K. 2014. Filsafat Barat Kontemporer:

Prancis (Terj. Mulyono). Jakarta: Gramedia.

Creswell, John W. 2014. Research Design:

Pendekatan Kualitatif, Kuantitatif, dan

Mixed (Terj. Achmad Fawaid). Yogyakarta:

Pustaka Pelajar.

Derrida, Jacques. 1976. Of Grammatology (Terj.

Gayatri Chakravorty Spivak). Baltimore:

The John Hopkins University Press.

Eco, Umberto. 2015. Teori Semiotika: Signifikasi

Komunikasi, Teori Kode, serta Teori Produksi

Tanda (Terj. Inyiak Ridwan Muzir). Yogyakarta: Kreasi Wacana.

Graham, Gordon. 2014. Teori-Teori Etika (Terj.

Irfan M Zakkie). Bandung: Nusa Media.

Kant, Immanuel. 1959. Founndations of The Metaphysics of Morals (Terj. Lewis White Beck). Indianapolis: Bobbs-Merrill Educational Publishing.

Levinas, Emmanuel. 1969. Totality and Infinity

(Terj. A. Lingis). Pittsburgh: Duquense University Press.

Maharani, Septiana Dwiputri. 2015. Konsep Etika Kepedulian Carol Gilligan dalam Perspektif Filsafat Manusia: Relevansinya Bagi Pemahaman Hubungan Antargender di Indonesia. Disertasi tidak diterbitkan. Yogyakarta: Universitas Gadjah Mada.

Nöth, Winfried. 2006. Semiotik (Terj. Dharmajo, dkk.). Surabaya: Airlangga University Press. Piliang, Yasraf Amir. 2003. Hipersemiotika: Tafsir Cultural Studies Atas Matinya Makna. 
Bandung: Jalasutra.

Prameswari, Ade Pupi. 2015. Praktik Politik

Dinasti pada Pemerintahan Daerah Kabupaten

Jombang (Ditinjau dari Perspektif Politik

Hukum). Tesis tidak diterbitkan. Yogyakarta:

Universitas Gadjah Mada.

Putera, Ramadi. 2017. Determinisme Teknologi dalam Perspektif Filsafat Teknologi Jean François Lyotard. Tesis tidak diterbitkan. Yogyakarta: Universitas Gadjah Mada.

Putra, Surya Desismansyah Eka. 2015. Pemikiran Sukarno Tentang Humanisme Ditinjau Dari Filsafat Manusia. Tesis tidak diterbitkan. Yogyakarta: Universitas Gadjah Mada.

Rancière, Jacques. 2004. The Philosopher and His Poor (Terj. John Drury, Corinne Oster, dan Andrew Parker). Dunham: Duke University Press.

Rizkiyah, Eva Laila. 2019. Deradikalisasi Keagamaan di Indonesia dalam Studi Kritis Humanisme Islam Nurcholish Madjid. Tesis tidak diterbitkan. Yogyakarta: Universitas Gadjah Mada.

Russell, Bertrand. Sejarah Filsafat Barat (Terj. Sigit Jatmiko, dkk). Yogyakarta: Pustaka Pelajar.

Sarup, Madan. 2011. Postrukturalisme \& Posmodernisme (Terj. Medhy Aginta Hidayat). Yogyakarta: Jalasutra.

Sobur, Alex. 2001. Analisis Teks Media: Suatu Pengantar untuk Analisis Wacana, Analisis Semiotik, dan Analisis Framing. Bandung: Remaja Rosdakarya.

Sobur, Alex. 2017. Semiotika Komunikasi. Jakarta: Remaja Karya.

Sugiyono. 2019. Metode Penelitian Kuantitatif, Kualitatif, dan R\&D. Bandung: Alfabeta.

Sygiyono. 2010. Memahami Penelitian Kualitatif. Bandung: Alfabeta.

Suseno, Franz Magnis. 2009. Menjadi Manusia: Belajar dari Aristoteles. Yogyakarta: Kanisius.
Suseno, Franz Magnis. 2018. Etika Politik: Prinsip Moral Dasar Kenegaraan Modern. Jakarta: Gramedia.

Tjaya, Thomas Hidya. 2011. Empat Esai Etika Politik: Tanggung Jawab Terhadap 'Yang-Lain' dalam Pluralitas-Etika Politik Emmanuel Levinas. Jakarta: Salihara.

Tjaya, Thomas Hidya. 2012. Enigma Wajah Orang Lain: Menggali Pemikiran Emmanuel Levinas. Jakarta: KPG. 